\title{
Contagious ideas: vulnerability, epistemic injustice and counter- terrorism in education
}

\author{
Aislinn O'Donnell \\ Mary Immaculate College, University of Limerick, Limerick, Ireland
}

\begin{abstract}
The article addresses the implications of Prevent and Channel for epistemic justice. The first section outlines the background of Prevent. It draws upon Moira Gatens and Genevieve Lloyd's concept of the collective imaginary, alongside Lorraine Code's concept of epistemologies of mastery, in order to outline some of the images and imaginaries that inform and orient contemporary counter-terrorist preventative initiatives, in particular those affecting education. Of interest here is the way in which vulnerability (to radicalisation) is conceptualised in Prevent and Channel, in particular the way in which those deemed 'at risk of radicalisation' are constituted as vulnerable and requiring intervention. The imaginary underpinning such preventative initiatives is, I argue, a therapeutic/epidemiological one. If attention is paid to the language associated with these interventions, one finds reference to terms such as contagion, immunity, resilience, grooming, virus, susceptibility, therapy, autonomy, vulnerability and risk - a constellation of images/concepts resonant with therapeutic and epidemiological theories and practices. I outline some of the implications of this therapeutic/epidemiological imaginary for epistemic injustice. If people, in this case, students, teachers and parents, feel that their voice will not be given credence, this leads to testimonial injustice. If one group is constituted as a suspect community, this risks hermeneutical injustice for that group-a situation facing Muslims at present. Given the requirements for educators and educational institutions to enact this particular iteration of preventative counter-terrorist legislation, the way in which vulnerability (to radicalisation) is understood and operationalised has direct bearing upon education and the educational experience of all stakeholders, in particular in relation to the conditions for epistemic justice.
\end{abstract}

\section{KEYWORDS}

Prevent; counter-terrorism; vulnerability; epistemic injustice; therapeutic education; contagion

\section{Introduction}

In this essay, I assess the potential impact for students and teachers of the counter-terrorism legislation called Prevent and the de-radicalisation programme Channel through a careful analysis of the implications of the appeal to the concept of vulnerability (to radicalisation). Whilst much has been written about the relationship between the War on Terror and education (Giroux, 2003), this essay is concerned with the risk of epistemic injustice as a consequence of discourses, policies, laws, and practices in counter-radicalisation and prevention of terrorism. My argument is that the 'imaginary' (a concept I will explain) that accompanies, and is constitutive of, the concept of (potential) vulnerability (to radicalisation), a concept that underpins counter-terrorist preventative strategies in education, risks 
epistemic injustice, both hermeneutic and testimonial, by in effect silencing and denying credibility to (Muslim) students, parents, and educators, especially those who contest Prevent, and by constructing a set of (implicitly) racialised, colonial frameworks that constitute Muslims as a suspect community (Bartlett and Birdwell, 2010; Bonino, 2013; Githens-Mazer, 2010, 2012; Hillyard, 1993; Hickman, Thomas, Nickels, \& Silvestri, 2012; Jackson, 2008; Kundnani, 2009, 2015; Mythen, Walklate, \& Khan, 2009; Pantazis \& Pemberton, 2009, 2011; Spalek, 2011).

Prevent also has implications for any student who adopts a dissenting or radical position that involves questioning, for example, fundamental British values (FBV) or British foreign policy. Non-violent extremist positions can, in principle, equally make one a target for de-radicalising or counter-radicalising interventions. However, authors like Kundnani (2014) argue that Muslims in particular are being racialised in counter-terrorist policies such as CONTEST (Counter-Terrorism Strategy). By marking out certain bodies as potentially carrying certain traits or dispositions by virtue of, for example, clothing, this produces disenfranchisement, exclusion, prejudice, racism, and Islamophobia. The question of racism in relation to epistemic injustice is deserving of greater consideration than I give it in this essay, even if it informs implicitly and explicitly much of what follows, in particular the sections relating to colonialism and contagion.

Under the Prevent Strand of CONTEST, the duty to prevent terrorism is now enforced by law for educators in the UK, as well as for workers across a range of other sectors. I have previously examined some of the problematic assumptions underpinning this legislation and the implications of referrals to Channel which has developed a multi-agency approach to people 'at risk of radicalisation', as well as others who are or who have been 'radicalised' (O'Donnell, 2016). There I argued that the way in which radicalisation is conceptualised in the pre-crime sphere has considerable implications for students who must question whether, and to what extent, they can speak freely (what Michel Foucault calls parrhesia) without risk of referral, as well as for freedom of thought in classrooms. In that essay, I argued that genuine education, as opposed to indoctrination, is by its very nature anti-extremist, requiring and demanding careful, rigorous and reasoned discussion of difficult topics in such a way that avoids the pitfalls of either relativism or forms of authoritarian 'liberalism' that rely upon a single narrative and refuse the complex, messy stories such as those of colonialism, empire, racism and Islamophobia. I suggested that the policy of Prevent risks silencing students and teachers, making very difficult the openness, fearless speech, trust, humility, and critical thought that are required for genuine engagement in education by all parties.

The Prevent strategy directly affects the lives of students and teachers, and the nature and experience of education, because by making it a statutory obligation for educators and institutions to prevent terrorism and to report students 'at risk of radicalisation', it securitises education. Indicators of vulnerability to, or potential risk of, radicalisation operate in the 'pre-crime' domain (McCulloch and Pickering, 2009): some students are potentially vulnerable and susceptible to perhaps becoming involved (at an indefinite future date) in terrorism. This is not based on evidence but rather on 'indicators' that are very generally defined (Russell Group, 2015), as I explain below. In this respect, the concept of vulnerability in Prevent policy documentation and toolkits is not simply a diagnostic category, opposed to resilience, but relies upon what has been called 'anticipatory' or 'pre-cautionary' logics. The use of such indicators prevails despite strong arguments made against the very concept of radicalisation by experts in terrorism studies, such as Horgan (2014) who consistently maintains that it is impossible to predict who will become a terrorist, even if one can describe how people may become terrorists. Indeed, Durodié (2016) writing about contemporary education states that the practices inaugurated with Prevent and Channel amount to the 'therapeutisation of security'.

The essay addresses three primary themes. The first section outlines the background of Prevent and introduces the concepts of the 'imaginary' and 'image', in particular in relation to the way in which vulnerability (to radicalisation) is conceptualised in Prevent. The second longer part examines the operation of what I call the therapeutic/epidemiological imaginary in respect of the constellation of images/ concepts and practices of intervention associated with this imaginary. The final part outlines some of the implications of this imaginary for epistemic injustice. Given the requirements for educators and 
educational institutions to enact this particular version of preventative counter-terrorist legislation, the way in which vulnerability (to radicalisation) is understood has direct bearing upon education.

\section{FBV, muscular liberalism and vulnerability}

In a speech in Munich in 2011, British Prime Minister David Cameron said that it was essential to be clear about where the origins of terrorism lay. They lie in the existence of an ideology of 'Islamist extremism', an extremist political ideology supported by a minority. He claimed that state multiculturalism had 'encouraged cultures to live separate lives, had not offered a vision of a society to which people want to belong' and had promoted a form of 'hands-off tolerance' leaving 'some young Muslims feeling rootless, looking for something to belong to.' Cameron's speech elides a number of issues. He distinguishes between Islam and Islamist extremism but then suggests that Muslim communities engage in unacceptable views and practices. He suggests that it is the sense of a lack of belonging has led to a process of radicalisation amongst young people, and his sole allusion to the implications of foreign policy is to say that'preachers of hate can sow misinformation about the plight of Muslims elsewhere' (Cameron, 2011). The solution appears to be twofold: to 'confront and undermine' the ideology of extremism and to build a common and shared British identity. What is required, he says, is 'a more active, muscular liberalism' He posits that exposure to non-violent extremist ideas can be a precursor to violence. Ultimately what this analysis legitimates is an intensification of the security framework through the introduction of the new legal duty to prevent terrorism, a commitment that had previously been requested on a voluntary basis from the first iterations of preventative counter-terrorism.

In July 2015, it was made a statutory obligation for a range of professionals from the crèche worker to the doctor to the university lecturer to prevent terrorism. They were also required to teach or communicate FBV. Counter-terrorism language moved from the'them vs. us' Manichaean discourse post 9/11, to 'battles of ideas', and then finally to a softer, quasi-therapeutic approach that images the potential home-grown terrorist as a vulnerable person who needs support. This model privileges the notion that the explanatory paradigm for terrorism requires identifying emotional and existential vulnerability, and the solution to terrorism involves addressing said vulnerabilities in the population. (This does not seem to allow for the possibility that some people may make a choice to take a particular route towards violence, and that they may be exercising agency in so doing.) The images mobilised by Prevent suggest that those who risk engaging in terrorism are passive and vulnerable subjects who have become 'infected' or 'gripped' by ideas, and who are thus in need of intervention and support, but they are also and simultaneously constituted as potentially dangerous. According to this logic, if the root cause of the radicalisation to violence is exposure to certain Islamic theological ideas, then these ideas must be rooted out and those populations susceptible to being influenced by such ideas must be identified. Instead of simply countering violent extremism, or, even more problematically, non-violent extremism, it is now those who are 'at risk of radicalisation' who must be identified, targeted and supported. In a critical essay that raises the issue of how those who hold 'extremist' ideas but who also hold to non-violence may be targeted under such legislation, Richards (2011) offers a careful reading of the inconsistencies of argumentation in Home Office documentation, pointing out that whilst some extremist ideas are obnoxious, the purpose of counter-terrorism legislation should be to counter terrorism and violent extremism, not to police ideas.

That there is little evidence that ideas or ideology cause terrorism, the fact there is no generic profile of the terrorist, and the likelihood is that a more complex confluence of factors bring people to use violence for political aims are all acknowledged in the Prevent documentation, yet despite this, it still suggests that professionals can be trained to identify the attitudinal and behavioural indicators of those at risk, and that these indicate whether someone is potentially on a pathway to terrorism. The documentation emphasises that the legislation will not infringe upon free speech and academic freedom, yet (and often in the same sentence) it also states that the existence of non-violent extremist ideas must be addressed. It uses powerful metaphors that images those 'extremist ideas' as a 'pool' or 'oxygen' in which terrorists can swim and breathe. The focus on ideas and beliefs, rather than violent methods, and 
the codified list of generic indicators of vulnerability under the categories of 'engagement', 'intent' and 'capability' (many of which in the first two categories would describe many citizens) seems to ignore some of the essential questions for any counter-terrorist strategy, such as: why do people choose to use violence to achieve their ends? Or more importantly, how can those who are actively seeking to engage in violence or terrorism be identified? How do people get involved? Holding radical or extreme ideas does not mean one will support or use violence (Bartlett \& Miller, 2012). A focus on ideas and potential pathways to radicalisation (to violence) is serving to create an environment of self-censorship and self-surveillance of those perceived as being 'at risk of radicalisation' (Brown \& Saeed, 2015; Kundnani, 2014, 2015). Mechanisms of surveillance are being embedded across those key societal institutions and organisations that engage with children and young people. Such pre-emptive interventions are often justified using language drawn from child protection and sexual abuse, in particular 'grooming'.

The concomitant requirement that educational institutions teach FBV implies that there is universal agreement in respect of the meaning of values and concepts such as democracy, rule of law, mutual respect and tolerance of different faiths and beliefs, and individual liberty. Despite claims to the contrary, it does not allow for or invite dissent or debate over these and alternative ethical and political concepts since extremism itself is defined negatively (and ambiguously) as 'vocal or active opposition to FBV' (HM Government, 2013, p. 1). Merely expressing 'non-violent extremist ideas' is seen as contributing potentially to radicalisation and to terrorism. The language of FBV also implies that some citizens are not sufficiently British or do not wish to be British, and that they have isolated and segregated themselves, but it doesn't permit the exploration of practices of discrimination, prejudice and racism that seek to exclude some from belonging to the body politic as full citizens, it does not investigate the legacies of Empire, genocide and slavery in the British imaginary, or allow for the disaffection that many citizens have with their State. It also does not acknowledge the consistent suspension of the law through emergency counter-terrorist legislation.

\section{Potential vulnerability and the 'risk of radicalisation'}

In order to understand how this concept of vulnerability (to radicalisation) has performative force in the everyday lives of students and educators, the concepts of 'image' and of the 'imaginary' are helpful. Image and imaginary are here understood to be constitutive of concepts and generative of lived practices of sensing, perceiving and conceiving, rather than simply illustrative of concepts. For example, Hobbes' famous image of the Leviathan does not simply illustrate an idea, but is constitutive of a particular concept of sovereignty. Similarly, the image of depositing is essential to grasp Freire's concept of banking education (and the ways in which many teachers understand the task of education). These images (this is what it means to teach, this is what it means to be sovereign) are co-constitutive of those concepts that orient different practices of acting, living and perceiving, such as educating. If, as is argued, collective and social imaginaries orient our political, social and affective lives, and shape our concepts (Code, 2006; Fricker, 2007; Gatens \& Lloyd, 1999), then understanding collective imaginaries means thinking about images as constitutive, generative and productive rather than as descriptive. For instance, when examining the ways in which vulnerability is mobilised in counter-terrorism legislation, policy documentation, and training, it is imperative to reflect on the histories and associations of terms associated with vulnerability, for example, contagion, therapy, immunisation, susceptibility, purity, colonialism, and autonomy.

Ecclestone and Hayes (2009) argued that we are witnessing a dangerous turn in therapeutic education with the increasing emphasis on the'vulnerable self'. The case of Prevent constitutes an intensification of such therapeutisation of education, by conceptualising vulnerability (to radicalisation) in terms of potential future risks rather than real existing risks. Given the statutory obligation to understand and locate indicators of vulnerability (to radicalisation), this shift also changes the role of the educator, the nature of relationships in classrooms, and ultimately the ways in which children and students imagine themselves and others (Brown \& Saeed, 2015). The strategies of Prevent and Channel (Department for Children, Schools \& Families [DCSF], 2008; HM Government, 2011, 2012, 2013, 2015; House of Commons, 
2010) are, I argue, underpinned by a therapeutic/epidemiological imaginary that relies upon a particular concept of vulnerability (to radicalisation). The conceptual apparatus and infrastructure that support this approach is drawn from psychology, public health, child protection (in particular in respect of resilience), criminology, and social work.

In this regard, this recent turn in preventative counter-terrorism with CONTEST 3 innovates significantly on the concepts of anticipatory and pre-cautionary logics as Prevent seeks to 'act before the threat of the terrorist has become manifest' (Martin, 2014, p. 66). It no longer retrospectively traces symptoms or 'potentials' from the (criminal) act of the person, but uses instead pre-emptive logics to attribute potential vulnerabilities, susceptibilities and dispositions to people who may have no intention to engage in violence and who have never engaged in violence. The shift from previous counter-terrorist discourses that relied on images like 'battles' of ideas and values to a softer, more interventionist and supportive framework is, paradoxically, perhaps even more disempowering for those who dissent from dominant norms, as now they will be classified as displaying psycho-pathological symptoms or emotional vulnerabilities that need treatment, rather than being treated as political dissenters and credible speakers. Contemporary counter-terrorism legislation extends the 'operation on the soul' from those institutions and bodies that were previously involved in carceral networks into a capillary securitocratic network that expands the web of institutions and professionals directly involved in performing security, counter-terrorist and intelligence functions. The purpose is to identify those 'at risk of radicalisation' and institute pre-emptive forms of intervention to de-radicalise, where judged appropriate.

\section{Collective imaginaries and epistemologies of control}

Instead of reiterating the criticisms of the concept of radicalisation as many others have done (Horgan, 2014, 2008a, 2008b; Kundnani, 2006, 2012, 2014, 2015; Sageman, 2014; Schmid, 2013; Sedgwick, 2010), I want to examine more carefully the constellation of images that orients discussions of radicalisation, and that underpins practices and interventions of de-radicalisation. I suggest that a number of these - contagion, vulnerability, susceptibility, risk, infection, grooming, virus, and germ - reveal the way in which epidemiological and therapeutic imaginaries are increasingly implicated in structures and practices of governance and government. MacDonald and Hunter's critical discourse analysis demonstrates the prevalence and privileging of terms like 'vulnerability', 'at risk' and 'resilience' and 'support' in UK counter-terrorist documentation. They identify the way which the 'vulnerable' subject [is constituted] through a novel modality of 'therapeutic discourse' (2013, p. 137), arguing that this invokes 'a register which enmeshes this 'imaginary' subject in the technologies of medicalisation. The effect of this is to diminish the claim of the medicalised subject that his/her behaviour is autonomous and self-determined (2013, p. 138). The focus on interventions that target the individual, and by extension the community, means that discussion of the complexity of other meso- and macro-factors that may bring someone to use violence in the service of political ends is bracketed or ignored. In proactive, preventative strategies to engage the individual and the community, images of sovereignty, autonomy, identity and purity are implicit, particularly through the oppositional use of the terms 'vulnerability' and 'resilience'. This is in terms of both a promised return to a state of psychological normalcy, autonomy, agency and 'resilience', and because of the suggestion with FBV that there is an unproblematic and monolithic ground of agreed values that can anchor the body politic. In this way, little attention need be paid to the histories of individual, political or social bodies, the differential access to institutions, the ways in which bodies are raced, classed and gendered, the sympathetic identification with civilians dying in conflicts abroad, and so forth. The image of 'active muscular liberalism' produces a particular kind of combative political imaginary against which are presented the allegedly sealed and isolated communities of multicultural Britain.

Our vulnerability, openness, interdependence and the contagious nature of our affects and ideas invite both sociability and antagonism according to Spinoza. However, with Prevent and Channel, such aspects of human experience tend to be pathologised and viewed as a problem or deficit, given the emphasis placed on fostering resilience. This approach seems to value the institution of a more sovereign 
and individualistic conception of autonomy in line with 'active and muscular liberalism' (Cameron, 2011). The language of resilience trades on ideas of immunity both in terms of personal resilience and the fortification of the boundaries of the sovereign state (Borradori, 2003) rather than com-munity (Esposito (2013). Images are not supplementary to our mental and affective lives but are constitutive of them. Spinoza understood the mind to be the idea of the body: anything that happens in the body is registered in the mind, and vice versa. The imagination is not simply a cognitive or mental affair but is material and registered through our body awareness: we are always aware of other bodies at the same time as our own. This susceptibility and openness to the emotions and ideas of others, and this experience of shared vulnerability and interdependence, are understood to be constitutive of the human condition. They are also that which allows us to develop our capacity to encounter more images, more ideas, to be affected in more diverse ways and thus to develop our powers of reason. To be able to be affected is a capability in Spinoza's model. The problem is with dogmatic and authoritarian images and organisations of power that seek to impose monolithic and generic ideas, often in order to secure relations of domination and passivity or to generate specific organisations of emotion around particular images.

Feminist scholarship from Le Doeuff (1989), Code (2006) and Gatens and Lloyd (1999) has long argued for a conception of images and the 'imaginary' that would pay heed to the way in which the images are constitutive of concepts (for example, 'identity'). They do not believe that philosophical concepts can or ought to be purged of the images that orient and ground them. Indeed, what is of considerable interest is the way that philosophy images and imagines itself. This kind of analysis is useful in appraising different imaginaries; how is security imaged, or how is education imaged? Code (2006) argues that images have constitutive effects and shares with Gatens and Lloyd (1999) the conviction that our ways of knowing and our ways of inhabiting the world are co-imbricated. Code wants to understand 'the metaphorics, images and symbolisms woven into dominant social-political imaginaries: to examine how they work to shape and govern possibilities of being, thinking, acting; how they legitimate or preclude certain epistemic and other human relations, to one another; how philosophical systems reflect and reinforce these imaginaries' (2006, p. 11). The instantiation of the therapeutic/epidemiological imaginary that we see with Prevent reveals a commitment to an interventionist image of mastery and control: knowledge here has a direct relation to power. However, epistemologies of control do not allow for the delicate and sensitive adjudication of competing claims and diverse imaginaries or the refinement of ethical sensibilities and development of contextual judgement. They venerate too much 'the mastery, efficiency and control modern science is imagined to provide' $(2006,11)$ instead of cultivating the conditions for co-habitation without consensus. They do not allow for personal stories and testimonies, preferring their claims to their own expertise and objectivity. This kind of approach imposes its framework deductively rather than thinking inductively in and from the specificity of the situation. Technologies and techniques of control, such as frameworks to assess vulnerabilities, add a veneer of scientific credibility and authority whilst foreclosing the kind of humility, questioning and uncertainty that ought to accompany the human encounter and that would create the conditions for genuine dialogue.

Like Spinoza, Gatens and Lloyd (1999) worry about those images and imaginaries that serve to dominate and subject others, diminishing the power and capacity of citizens to exist, to act and to think. Where images and imaginaries silence the voice of someone, or their words are interpreted through a medicalised lens of pathology, this corrodes and fragments the social body and the possibility for those forms of common life that rely on giving credence to one another as speakers. The purpose of democratic government should be to help us to develop our powers of understanding so that we might make use of our lives. Like Code (2006), Gatens and Lloyd (1999) think that our ways of knowing are our ways of being and these are lodged in our political, social and educational institutions. If we take this seriously, this means that we have to reflect on the images through which we understand ourselves, our relation to others, and our conception of the polity.

Through that exercise in understanding, we can also come to understand the associational paths of our bodies in relation to different images and the ways in which the qualitative nature of our experience varies through such encounters: for example, what associations come to mind when I hear a certain 
accent? Even though we are determined, we can also be transformed through our understanding of how we are determined. This is not to suggest that one can transcend, through reason, emotional and social life but rather it acknowledges that our sociability and our reason stems from our dependence on other bodies. In this way we understand why emotions are contagious and why we identify with and imitate others. All of this constitutes the fabric of social life and is grounded in our interdependence and the way in which our body awareness is always mixed with the awareness of other bodies, present or imagined. This kind of analysis and diagnosis is attuned to vacillations of affective life, to antagonism and to love and friendship. It doesn't imagine a monolithic conception of the collective imaginary - agreement does not mean sameness or consensus on this model - but rather seeks out ways in which we can better live together. Different words and images can separate and unite us, and we exist in networks of circulating affects and ideas, but we can find also ways of developing imaginaries that divide us less and that allow for more forms of conviviality and friendship. This political philosophy is premised upon a relational ontology that is far from the dichotomy of muscular or authoritarian liberalism or monolithic communalism that recent iterations of Prevent seem to suggest are the sole political options in British society.

Understanding the genealogies of social bodies can help us to develop sensitivity to the historical and contemporary resonances of concepts, like contagion or resilience, and to grasp the way in which images and metaphors have real effects. This might invite more consideration of the implications of the language and interventions adopted by Prevent and Channel, and the way in which a dominant social imaginary through FBV and muscular liberalism is being imposed on those presumed to be 'different' or not 'integrated', such that it de-legitimates counter-voices and counter-images, and even other imaginings of what it means to be British. There may be echoes in all of this of what Gilroy (2004) calls'postcolonial melancholia' in the dominant political imaginary of FBV given the lack of willingness to confront present or historical wrongdoing or to explore the possible legitimacy of the 'grievances' of others. Indeed, Rogers (2008) questions the wisdom of using divisive language in such matters. A peculiar imaginary of insularity, revisionism and dogmatism is perpetuated when any admission of fallibility and error or any broaching of questions of collective responsibility appears ruled out of play. Even what Gilroy calls the 'unruly multiculture' of ordinary life and interactions remains unacknowledged in Cameron's image of siloed multicultures. Gilroy prefers to remind us of the'radical openness that brings conviviality alive [and that] makes a nonsense of closed, fixed and reified identity, and turns attention toward the always unpredictable mechanisms of identification' (2004: xv).

Images, fictions or collective 'illusions' are not bad, per se, but they cannot be simply transcended by reason. Images are often, at least partially, constitutive of normative ethical and political life. They move us and they organise our affective lives and the investments of our desires. But there may be more creative ways of imagining ourselves and our body politics. Whilst one is wise to be vigilant in respect of identifying those images and ideas that generate sad passions, divisions and exclusions, there are also always opportunities to foster those that cultivate potentials for understanding, speaking, listening and conviviality. So many elements of convivial existence remain invisible and unnoticed when more powerful and monolithic images dominate and divide the political imaginary into those who belong by nature and birthright, and those who are 'othered'. Gatens and Lloyd draw upon Tully's (1995) image of 'strange multiplicity' and his conception of 'critical freedom' in order to explore relational and transindividual ideas of the body politic that do not image differences and identities as homogeneous or monolithic but rather see them as partial, inter-woven and cross-cutting. The contagion of our affective lives provides the ground through which we can come together, share our ideas, and better notice the tiny, often scarcely noticed, ways in which we already find ways of co-habiting or resisting together.

\section{Images of vulnerability, contagion and resilience}

In Mark Sageman's provocative response to recent terrorist research initiatives, he says 'The key assumption behind this "Blame it on Islam" explanation of terrorism was that there was some mysterious process of indoctrination or brainwashing that transformed 'vulnerable' or 'at risk' naïve young people into 
fanatic killers or true believers (2014, p. 567). He ridicules the idea that'sinister Al Qaeda agents lurking in the shadows of mosques spotted naïve Muslims based on some personal vulnerability ('at risk') and turned them over to recruiters' (2014, p. 567). He argues that there is no evidence that these spotters/ recruiters exist and nor is there any real insight, despite all the research, as to what leads young people into political violence, although some answers can be given in respect of the 'how'. He understands how the lack of empirical research, the politics of terrorism research, the lack of access to information, and the relative rarity of terrorist events in Europe and the US means that a lack of specificity generates far too many false positives. It is this that should be of concern when making it a statutory duty to prevent terrorism. The erroneous referral of young people to Channel has meant that in the case of $80 \%$ of referrals no grounds for concern are subsequently found. However, it is difficult to imagine that this referral or suspicion will not affect the child or young person, the family, the teacher and the school, or those other children and young people who fear being referred.

Prevent allows for the law to reach into the space of education, making explicit the legal requirement that teachers and lectures engage in counter-terrorist work by looking out for those students at 'risk of radicalisation' and by teaching FBV. It is stated, without evidence, that 'extremists take advantage of institutions to share their poisonous narrative with others, particularly with individuals vulnerable to their messages' (HM Government, 2013, p. 5). Given many people hold extreme or radical ideas and yet do not resort to violence, it is difficult to argue that the origin, cause or root of violent extremism lies in ideas or ideology, as it implied by policies like Prevent, and it is dangerous to suggest that these ideas provide the 'pool', 'oxygen' or 'environment' in which violent extremist ideas breed and mutate.

This policy position is somewhat at odds with some of the more tempered conclusions of a rapid evidence assessment called Understanding vulnerability in individuals to the influence of Al Qa'ida violent extremism that was commissioned by the Home Office (2011). It distinguished more clearly between radicalisation that involves support for terrorism and violent extremism, and radicalisation that involves views different from the mainstream but which does not support violence. Some of the psychological factors that they assess make someone vulnerable to AQ-influenced violent extremism include a crisis that leads to an 'individual re-evaluating previously held beliefs and being open to new ideas' ( $p$. iii) and they suggest that 'political ideology and grievances are consistent motivating factors' ( $p$. iii) for involvement in AQ-influenced violent extremism with some acting in vengeance for attacks. In the West, an important driver is the 'perceived injustice and violence against Muslims around the world' ( $p$. iii) as well as other factors like status, power, money and so forth. They argue that radicalisation to violent extremism is a social process and that charismatic leaders can play a role, although recruitment tends to take place in private spaces and through the internet. They admit that there is little empirical evidence that could explain either vulnerability or resilience and they define risk or vulnerability factors as follows:

A risk factor or vulnerability factor is defined as an attribute, characteristic, condition or context that increases the probability of support for, or involvement in, violent extremism, or an increase in the level of involvement in violent extremism.

A protective factor or resilience factor is defined as an attribute, characteristic, condition or context that reduces or buffers the effect of one or more vulnerability factors, to prevent the move toward violent extremism. $(2011$, p. 3)

Yet the report concludes that 'the empirical evidence base on what factors make an individual more vulnerable to Al Qa'ida (AQ)-influenced violent extremism is weak. The evidence base on resilience to AQ-influenced violent extremism is even less well developed [...]' (2011, p. 36). Bartlett and Miller (2012) counsel against conflating violent and non-violent radicalisation, however the Channel Vulnerability Assessment Framework (2012) appears to ignore this advice by outlining 22 risk factors under three categories of engagement, intent and capability, which it examines separately. It does not sufficiently distinguish the factors listed under the first category Engagement with a group, cause or ideology from those of the second category of Intent to cause harm. Called 'psychological hooks' that describe'susceptibilities, motivations and contextual influences and together map the individual pathway to terrorism' $(2012$, p. 3), the list under Engagement includes 'Feeling of grievance and injustice; feeling under threat; a need for identity, meaning and belonging; a desire for status; a desire for excitement and adventure; 
a need to dominate and control others; susceptibility to indoctrination; a desire for political or moral change; opportunistic involvement; family or friends involved in extremism; being at a transitional time of life; being influenced or controlled by a group; relevant mental health issues' $(2012$, p. 3). In the second category of Intent, there are no indicators of specific intent, instead more generic indicators are listed, including:'over-identification with a group or ideology; 'Them' and 'Us' thinking; dehumanisation of the enemy; attitudes that justify offending; harmful means to an end; harmful objectives' (2012, p. 3). The final category of Capability to do harm examines logistical and material capabilities as well as knowledge and is the only category which seems appropriate in terms of a counter-terrorist strategy.

It is not clear how the assessment in Channel is ultimately made and what role the different categories play. Given the secrecy of the programme, and the consensus that most of those who adopt terrorist tactics are ordinary and they come from a wide variety of backgrounds, it is unclear how these indicators are helping to identify those who are most likely to undertake a violent attack. But one cannot prove what has never materialised in the first case. More importantly for educators is what this vulnerable assessment framework means for children and young people. Given the latitude for interpretations of most of those indicators that suggest that someone might be 'at risk of radicalisation', how secure can they feel about voicing their perspectives and experiences? Foucault (2003, 2005, 2006,2007 ) and Goffman (1987) amongst others have shown the way in which a medical diagnosis or a criminal conviction changes the way in which someone is seen or heard, and the way in which they come to experience and imagine themselves. If someone is identified as 'potentially at risk', or thinks that someone else might identify them as 'at risk', one's statements are read, even by oneself, through a different therapeutic and medicalised lens such that very ordinary statements and feelings can end up being pathologised through the encounter with an 'expert' discourse. 'Perhaps of most concern is that, despite their fundamental shortcomings, such approaches are currently being used to provide the intellectual justification and the technological 'know-how' for normalising state practices of discipline and social control of Muslim children and young people - all in the name of 'safeguarding' them' (Coppock \& McGovern, 2014, p. 248).

\section{Images of moral contagion and public health}

Heath-Kelly argues that vulnerability is coupled with riskiness and 'the language of (susceptibility to) persuasion, disadvantage and vulnerability is used to create a vulnerable potential terrorist subject separate from existing radical subjects (who prey on the weak, promote contagious ideas and take advantage of our'open institutions')' $(2013$, p. 404). This ambivalence as to whether subjects are potentially vulnerable or risky is exemplified by the hesitant and provisional language of 'might' and 'could' and 'some' that populates preventative counter-terrorist documentation. This language of susceptibility, vulnerability, riskiness and resilience is also mobilised in epidemiological models that develop preventative measures for public health. Indeed, the metaphor of virus or disease has been invoked both to describe terrorism and to describe extremist or radical ideas. In a problematic essay, Stares and Yacoubian (2012) explicitly adopt a public health approach to terrorism. This plays on the image of a body politic warding off infection. Indeed, they suggest that terrorism should be imaged as a 'virus' that can lead to infection. Arguably however, this epidemiological shift is also what is at play in the efforts to locate those individuals and populations 'susceptible' and 'at risk' of succumbing to radicalisation. It justifies pre-emptive intervention and the efforts to bolster immunity and resilience. However, there is, of course, significant danger in imaging political ideas as viruses, diseases or microbes, as it risks, quite literally, pathologising dissent. Stares and Yaboubian (2007) describe the way in which disease metaphors populate terrorist discourse in particular in relation to Islamist ascendancy, and they point to phenomena of 'social contagion', but then take those images of terrorism as 'microbe', 'disease', or 'virus' as offering a potential explanatory and predictive framework, premised upon public health initiatives, which could diagnose those populations and individuals at risk of the terrorist'virus'. By imaging terrorism as a virus or disease that has particular and identifiable vectors, they explicitly lay claim to the scientific credibility offered by epidemiological and public health approaches (to disease). 
For example, they describe militant Islamist ideology as an 'agent' with two primary strains. Hosts are groups or persons infected with the agent (militant Islamist ideology) and the environment refers to likelihood of exposure (conflict, alienation etc.). Vectors (prisons, madrassas, mosques, etc.) are used to propagate the ideology. However, whilst virulent, it seems that the majority of Muslim populations are inoculated or 'immunised' against this virus, although some Muslims remain 'susceptible' (2007, p. 8-9). They describe the policy benefits of this epidemiological model and the way in which public health campaigns typically contain the threat, protect high-risk groups, and remedy the environmental conditions. They acknowledge that containment measures risk harming civil liberties so there are limitations in respect of direct interventions, but they suggest propagating 'ideological antidotes' (2007, p. 13). Now, whilst this epidemiological model is not expressly referred to within the Prevent literature, the language of 'resilience,' 'immunity,', 'vulnerability', 'susceptibility', 'risk' and indeed 'partnership' are resonant with approaches to public health. Stares and Yacoubian's suggestions bear some similarity to the kind of approach adopted by the British government, in particular engaging with moderate voices so that they can influence opinion, and interventions that 'approximate health care's attempts at treatment and rehabilitation of the infirm' (2007, p. 14). 'Ideological immunisation', they also say, 'should offer a positive and compelling alternative vision for the future' (2007, p. 16). However, unlike Prevent, they argue that efforts at remedial measures should be made to resolve violent conflicts that have a strong resonance with the Muslim world, and that the source and not the symptoms ought to be addressed. It is, perhaps, not unsurprising that one would see elements of this epidemiological approach in Prevent and Channel, but given that having an idea is presumably not quite the same as having a disease or infection, what does it mean for those populations identified as 'at risk', especially for those communities and individuals seen as in need of immunisation against certain ideas? What does it mean to immunise certain communities against certain ideas or to suggest some communities are more susceptible? The images of immunisation, contagion and infection are powerful ones, which preclude other strategies such as critical conversations about difficult and complex topics. How does one experience and image oneself if one cannot know, in advance, if one is at risk, susceptible, or infected? Indeed what would it mean to claim that extremist idea already lies within a person, co-habiting, like the HIV virus before symptoms are displayed? Can ideas lie dormant like viruses? Is the treatment for an idea a stronger alternative idea, like FBV? These are metaphors but they have real and material effects, in particular when mobilised as part of a wider constellation of concepts (resilience, immunity, and so forth). Kundnani says that attention is now on'the circulation of 'extremist ideas', seen as a kind of virus, able to turn people into violent radicals. This then leads law enforcement agencies to try to prevent exposure to this virus, whether it be via books, websites, preachers or radical activists' $(2012$, p. 10). Aspects of Le Bon's (2001) theory of crowd psychology also appear implicit in this documentation, in particular in relation to the way in which one can become susceptible to and held hostage by ideas. Interest in the porous body and mind by nineteenth-century thinkers had led to them viewing those who were susceptible to contagious influences as having both weakened defences and a compromised capacity for self-control (Forth, 2001, p. 64). Forth adds that

In this sense moral contagion represented a double capitulation to the outer world of 'contagious ideas' and to the inner world of affects and drives: the external 'other' seemed to form an alliance with the sensual 'other' within. Not only does this suggest an eruption or uprising as well as a penetration, but it indicates that on an unconscious level the individual welcomed the collapse of the will that contagion entailed. (2001, p. 64)

Such minds were described as both effeminate and in microbiological terms. It was seen as necessary to 'transform one's inner garden into an inhospitable place for infectious thoughts' (2001, p. 68). In this way one could protect oneself from 'dangerous invasions' $(2001$, p.68). It is this image of 'contagion' that seems to be shaping the idea that certain people and communities can be 'susceptible' or 'vulnerable' to extremist ideas or radicalisation. It is not clear that warding against this would either invite or involve robust critical discussions and enquiry in schools and communities, in particular if students (and their parents) are worried about being identified as at risk, or metaphorically quarantined through referral to Channel. Rather than reflecting on our mutual vulnerability, or the vulnerability of the human condition, 
it is a particular community, Muslim people, which is deemed most susceptible and vulnerable to radicalisation and to harbouring infectious ideas or the conditions in which those ideas can propagate.

When Coetzee described the metaphors of contagion and infection at play in colonial and apartheid discourses, he looked at the way in which certain groups and individuals are seen as more suggestible or susceptible to infection by 'the germ of an idea' (1996, p. 182). It is as though certain ideas ('ideological' ideas) do not serve as means to ends or to legitimate actions but rather they float ready to infect whole populations (1996, p. 183). One can easily be contaminated. In describing the experience of censorship, he says that the 'censor is typically experienced as a parasite, a pathogenic invader of the body-self, repudiated with visceral intensity but never wholly expelled' (1996, p. 10). The difference between the ontological claim that certain populations or individuals are particularly receptive and susceptible to certain kinds of ideas and the existential description of the gnawing doubt experienced by those censored is important. It is not that we could or wish to never be influenced, but rather that certain images of vulnerability and risk corrode our sense of being by undermining our capabilities and opportunities for knowing, through the encouragement of incessant self-questioning and paranoid doubt and the way in which we have been identified by (colonial) others as being at risk. As has already been argued, preventative counter-terrorism strategies are mobilising powerful medical, epidemiological and pastoral images in such a way that they are, wittingly or not, silencing the voice of those who might wish to question such strategies, or even those who might wish to engage in and encourage the kind of critical community of enquiry that one finds in those classrooms that are most alive with ideas.

\section{Anticipatory logics: undermining credibility and communication}

Given Gatens and Lloyd's (1999) reflections on the importance of images in social and political imaginaries, in particular in relation to their constitutive and generative effects, there are arguably real implications when images of 'vulnerability,',resilience,'support' and so on are privileged in Prevent and Channel. A pastoral approach to security allows for interventions to be framed through the duty of care, and State involvement in the sphere of private religious beliefs is legitimated by labelling Muslim communities as vulnerable to violent extremism (2011, p. 168). Counter-terrorist work is deemed akin to pastoral governance, concerned with the well-being of the individual. Finally, this medicalises, as MacDonald and Hunter note (2013), the relationship with students and the educational situation, making what are quite ordinary facets of the human condition problematic, pathological or deficits. All of this undermines the capacity for agency and resistance of those subjected to such programmes, and augments the fears of students who worry about being referred should they speak their minds. Dissent and disagreement with a professional over a medical diagnosis is seldom seen to be legitimate, wise or warranted, and the therapeutic/medical discourse privileges the authority of the expert voice and the scientific nature of the techniques of assessment and measurement. This epistemology of mastery claims knowledge in order to intervene and control, and it devalues the dissenting voice such that the person quite literally cannot be heard. This can be done by suggesting that the person is deluded, immature, manipulated, and so on. An equivalent demand for humility, criticality and self-reflexivity is not asked of the professional, be it the one who refers or the one who diagnoses. That said, many educators are both very much aware of their own limitations and deeply concerned with the implications of Prevent for their practice and for ethical relationships with their students.

In his thesis, 'Autonomy in Education', Brian Collins explains how the moment that one is constituted in a particular way as criminal, prisoner or mad, one is no longer heard or listened to as one was before. It is as though an act of trans-substantiation has taken place such that what was previously innocuous is now seen as symptomatic of a pathology. Drawing on Foucault's writings, in particular the concept of the Psy-function, he suggests this involves'attempts to harness the unpredictable nature of thinking through the policing of the speech act' (2014, p. 138). To question the Psy-function, or the colonisation by psychological discourse of an increasing number of domains from education to security, is not to suggest that there are not some children and young people who are vulnerable to manipulation, but rather to maintain that the pathways into terrorism are complex, and a strategy that targets indiscriminately 
entire populations as 'potential terrorists' risks alienating those young people, not to speak of denying them the rights of full citizenship. The range of indicators that purport to show that someone is 'at risk' means that if we take them literally, a constant state of self-reflexivity and self-doubt is engendered since one does not know for sure whether one might be displaying those symptoms that could reveal one to be 'at risk'. Any one of us is a potential terrorist.

Hook, writing of Foucault, explains that 'The examination is not limited to the past, to the single deviant or criminal act that has already taken place, it is a measure of the subject's future capability, their prospective dangerousness to society' (2010, p. 16). In 1984, Orwell's description of Winston's dilemma shows how one must develop a perpetual self-reflexive and self-scrutinising awareness that is grounded in the possibility of being seen, rightly or wrongly, in a certain light.

There are certain ideas that are bad. It was terribly dangerous to let your thoughts wander when you were in any public place or within range of a tele-screen. The smallest thing could give you away. A nervous tic, an unconscious look of anxiety, a habit of muttering to yourself - anything that carried with it the suggestion of abnormality, of having something to hide. In any case, to wear an improper expression on your face (to look incredulous when a victory was announced, for example) was itself a punishable offence. (1961, p. 79)

Foucault believed that a subtle system focusing on potential behaviours emerged from workshop disciplinary practice in the eighteenth century. He writes, 'One must be able to spot an action even before it has been performed, and disciplinary power must intervene somehow before the actual manifestation of the behaviour, before the body, the action, or the discourse, at the level of what is potential, disposition, will, at the level of the soul' (2006, p. 52). Pre-cautionary and pre-emptive logics operating in the space of pre-crime inform policies like Prevent (Heath-Kelly, 2012). The intent and outcome of these disciplinary practices and techniques is that one comes to police oneself, one's peers and one's students and patients. Hook claims that 'disciplinary problems hence advance by taking what were essentially political problems (problems of control), removing them from the domain of political discourse, recasting them into the neutral language of science and transforming them into technical problems for the sole attention of specialists and expert' $(2010$, p. 21). Whilst he argues that such approaches are pre-emptive, in that they are prior to the translation of intention into act, the significant innovation with Prevent and Channel is that referrals and interventions are now precautionary (Aradau \& Van Munster, 2007), speculative, and, in principle, prior to any indication of intent on the part of the person referred, in that one may show the signs and symptoms indicating that one is 'at risk' without either intent or action. It is not, however, permissible to profile in such a precautionary or speculative manner (Hadjimatheou, 2011) given the considerable risk of harm. Martin (2014) makes a careful conceptual distinction between pre-cautionary and pre-emptive logics and provides an analysis of both Prevent and Channel interventions. He argues that through invoking care, Channel can govern (counter-) radicalisation at a distance through expertise and by using a range of professionals enmesh responsibility for (counter-) radicalisation throughout society. These interventions are seen as non-political and enacted through a duty of care. Martin describes these interventions as both medicalising and pastoralising.

What are the effects of this kind of therapeutic imaginary that seeks to identify those 'vulnerable' to or 'at risk of radicalisation' or in need of 'support'? By positioning the image of vulnerability as problematic (Ecclestone, 2012), it privileges a sovereign conception of autonomy as opposed to which it presents the vulnerable person as someone 'at risk'. Such a person appears to be wholly passive, susceptible, and prey to virulent and powerful ideas. Coppock and McGovern (2014) argue that this demonstrates the tendency to psychologise social problems: terrorism is now explained by emotional dysfunction. Prevent operates with a deficit model, privileging positive psychological outcomes of well-being, rather than interrogating the ways in which children and young people explore ways of belonging, developing agency, finding significance and committing to ideals or resisting injustice. It does not investigate, as Scott Atran, (2015) suggests, the idealism, desire for justice, quest for meaning, compassion, and utopianism that often motivate young people, including those who join groups like ISIS, nor does it take seriously the expression of foreign policy grievances including the deaths of tens of thousands of people as a consequence of conflicts that involve the UK, the US and others. The effect 
of this particular image of vulnerability is to silence and to create self-doubt and fear (Durodié, 2016; Choudhury \& Fenwick, 2011). Indeed, Coppock and McGovern argue that'vulnerability is framed within specific, and again deeply problematic, conceptions of young people's mental health and well-being' and this means that young British Muslims are being 'rendered as appropriate objects for state intervention and surveillance' (2014, p. 242).

\section{Conclusion: the risk of pre-emptive testimonial injustice and the prospect of hermeneutical injustice}

From research in Muslim communities, Mythen argues that the consequence of Prevent and Channel is that 'a range of speech gaps were described, ranging from being unable to openly share political opinions, to a lack of representation in public affairs and a feeling of being ignored by government in the formation of security policies (2012, p. 418). One participant says 'That's what's so frightening about the laws being brought in. Not only do they make you check yourself all the time, but think about what could happen' (2012, p. 418). Others say'Yeah they talk about freedom of speech, but where's the freedom of speech for us?' and 'We don't have freedom of speech. Democracy is for white people' (2012, p. 418). Mythen reflects upon these young people's fears about being 'labelled as a terrorist sympathiser' and their 'uncertainty about the reach of counter-terrorism law' (2012, p. 421).

So many indicators can serve as potential symptoms or markers of risk, especially if one is a Muslim, that speaking freely becomes ever more difficult. Not only the student but also the teacher or lecturer must engage in constant self-scrutiny, since the implications of error are so serious in a 'risk society'. Democratic polities ought, at least according to Spinoza, to foster public communication and the exchange of ideas, but these policies, regardless of their intent, undermine this by making students and their families, in particular Muslims, fearful of speaking freely. Imposing an interpretative framework on the words of another means that they are not given the opportunity to explain themselves and their perspectives. This is particularly of concern in those cases where people are worried that what they say, even when they do not support violence, may lead to referral under counter-terrorism legislation.

The aspiration to codification - not to be confused with the (entirely honourable) ambition to make explicit any general principles that may usefully be extrapolated from virtuous sensibility - is revealed as an impulse to take refuge in a bogus objectivity; an impulse, that is, to evade the indefinite creative demands made on one by ethical life. (Fricker, 2007, p. 75)

Images circulate and operate in society in powerful ways and different affective regimes cluster around different images. This has particular force when someone's being, words and/or actions is interpreted through the lens of a constellation of images that constitute particular (kinds of) people as more potentially vulnerable or at more potential risk of radicalisation. Moreover, dominant collective social imaginations also shape responsiveness to the credibility of statements of different speakers. Kundnani (2014) has documented some of the difficulties experienced by young people referred to Channel in terms of their ability to challenge the very idea that they required de-radicalisation, and to be listened to and taken seriously. Miranda Fricker explains that some voices are not given the same credibility as others - some have a credibility excess and others a credibility deficit $(2007, \mathrm{p} .17)$. In the case of a credibility deficit, she argues that this constitutes a particular kind of epistemic injustice'in which someone is wronged specifically in her capacity as a knower' (2007, p. 20). Epistemic injustice is an ethical issue and not simply a matter for epistemology because there are structural and ideological considerations that render some voices, prima facie, untrustworthy or unreliable. Testimonial injustice tends to be systematic and related to wider forms of identity prejudice. She describes this as an identity-prejudicial credibility deficit' (2007, p. 28). This means that certain speakers are given less credibility in the credibility economy, whilst others are given more credibility (like middle class, middle aged, white males). Another form of testimonial injustice takes place in silence and silencing. 'It occurs when hearer prejudice does its work in advance of a potential informational exchange: it pre-empts any such exchange' (2007, p. 130). She calls this 'pre-emptive testimonial injustice' and the element of her analysis of this concept that has most bearing on our appraisal of Prevent legislation is her argument that 
the credibility of such a person on a given subject matter is already sufficiently deficient in prejudicial deficit that their potential testimony is never solicited; so the speaker is silenced by the identity prejudice that undermines her credibility in advance. Thus purely structural operations of identity power can control whose would-be contributions become public, and whose do not. (2007, p. 130)

Prevent and Channel through emphasising and codifying indicators of 'vulnerability,'susceptibility' and so forth, and by instituting relations of 'care' and 'pastoral governance' serve, a priori, to diminish the credibility of certain populations by constituting some people as 'potentially' risky or suspect, and by instituting unequal hierarchies of power that privilege 'expert' discourses, even when the evidence for such approach lacks credibility in the wider field of research on terrorism. Even if the legislation purports to address all extremist ideas and all those at risk of radicalisation, the primary focus is, de facto, on Muslims. The circulation of these images, and the association with Muslims, generates different kinds of affective investments. These influence which people are seen as more or less credible. Fricker argues that'testimonial injustice excludes the subject from trustful conversation. Thus it marginalises the subject in her participation in the very activity that steadies the mind and forges an essential aspect of identity - two processes of fundamental psychological importance for the individual' (2007, pp. 53-54). It is the concept of 'psychic alienation', derived originally from Fanon, that perhaps best captures the kinds of debilitating paralysis and self-doubt that stops one from speaking for fear of how one will be heard or constituted, in particular when one risks being constituted as 'at risk'. Foucault's descriptions of cases in Psychiatric power (2006) explains well how some speakers will not be heard in the same way once they are categorised as prisoner or patient (or even the person 'at risk of radicalisation'), as the hearer will often not retain the same testimonial sensibility when listening to these subjects. In any case, the speaker's concern and perception that she will not be heard or will be misinterpreted risks engendering the experience of 'psychic alienation'. It is here that the demands of epistemic justice may clash with the claims of expert judgement.

The use of preventative interventions to secure public and individual safety is familiar but Paul Gilroy has argued that a more accurate description of our contemporary political systems is 'securitocracy'. The implications of preventative counter-terrorist strategies for epistemic justice and the unequal distributions of the economy of credibility warrant further investigation, in particular given what we know about how people, once labelled by an expert or authority, have such difficulty in contesting those labels, be it in the case of the psychiatric patient or that of the colonised person. Not only do we need to reflect on the dominant collective imaginaries reflected in the language of preventative counter-terrorism, in particular those that mobilise epidemiological and therapeutic images which have implications for hermeneutical justice, but we ought also to consider whether challenging ideas ought to be in the remit of security agendas if those ideas do not have a direct relationship with violence. Given the nature of identity prejudice, stereotype and bias, the issue of epistemic injustice is inseparable from that of collective social, political and educational imaginaries.

And finally, we need to think about the implications of these strategies in terms of testimonial injustice, in particular pre-emptive testimonial injustice, and hermeneutical injustice, and for radical and critical thought and activism. What will it mean if generations of Muslim young people are afraid of speaking their minds in schools and universities for fear of being misrepresented and misheard? What are the implications of refusing to distinguish clearly between violence and non-violence in counterterrorism? If our ways of being and our ways of knowing are co-imbricated, what does it mean to be fearful of speaking freely? How will the requirement that educators operate as counter-terrorist informants impact upon relations of trust and honesty in classrooms? And finally, how can the securitisation of education be challenged and resisted, and what are the implications of not doing so for our polities?

\section{Disclosure statement}

No potential conflict of interest was reported by the author. 


\section{Notes on contributor}

Aislinn O'Donnell is Professor of Education in Maynooth University. Her writing, teaching and research involve engagement in a range of formal settings, such as schools, as well as informal settings and non-traditional sites of learning, including closed institutions. These spaces become research sites offering opportunities for co-enquiry in philosophy and cognate disciplines. This approach is influenced by contemporary art practice and research.

\section{ORCID}

Aislinn O'Donnell iD http://orcid.org/0000-0003-4570-8793

\section{References}

Aradau, C., \& Van Munster, R. (2007). Governing terrorism through risk:Taking precautions, unknowing the future. European Journal of International Relations, 13, 89-115. doi:10.1177/1354066107074290

Atran, S. (2015, November 15). Mindless terrorists: The truth about ISIS is much worse. The Guardian. Retrieved from http:// www.theguardian.com/commentisfree/2015/nov/15/terrorists-isis

Bartlett, J., \& Birdwell, J. (2010, July). From suspects to citizens: Preventing violent extremism in a big society. Demos. Retrieved March 10, 2015, from http://www.demos.co.uk/files/From_Suspects_to_Citizens_-_web.pdf?1279732377

Bartlett, J., \& Miller, C. (2012). The edge of violence: Towards telling the difference between violent and non-violent radicalization. Terrorism and Political Violence, 24, 1-21. doi:10.1080/09546553.2011.594923

Bonino, S. (2013). Preventing Muslimness in Britain:The normalisation of exceptional measures to combat terrorism. Journal of Muslim Minority Affairs, 33, 385-400. doi:10.1080/13602004.2013.853977

Borradori, G. (2003). Philosophy in a time of terror: Dialogues with Jurgen Habermas and Jacques Derrida. Chicago, IL: University of Chicago Press.

Brown, K., \& Saeed, T. (2015). Radicalization and counter-radicalization at British universities: Muslim encounters and alternatives. Ethnic and Racial Studies, 38, 1952-1968. doi:10.1080/001419870.2014.911343

Cameron, D. (2011). PM's speech at Munich Security Conference. Retrieved November 17, 2015, from http://webarchive. nationalarchives.gov.uk/20130109092234/http://number10.gov.uk/news/pms-speech-at-munich-security-conference/

Choudhury, T., \& Fenwick, H. (2011). The impact of counter-terrorism measures on Muslim communities. International Review of Law, Computers, and Technology, 25, 151-181.

Code, L. (2006). Ecological thinking: The politics of epistemic location. Oxford: Oxford University Press.

Coetzee, J. M. (1996). Giving offense: Essays on censorship. Chicago, IL: University of Chicago Press.

Collins, B. (2014). Autonomy in Education. Masters by Research submitted to Mary Immaculate College. University of Limerick.

Coppock, V., \& McGovern, M. (2014). “Dangerous minds": Deconstructing counter-terrorism discourse, radicalisation, and the "psychological vulnerability" of Muslim children and young people in Britain. Children and Society, 28, 242-256.

Department for Children, Schools and Families (DCSF). (2008). Learning together to be safe: A toolkit to help schools contribute to the prevention of violent extremism. Nottingham: DCSF.

Durodié, B. (2016). Securitising education to prevent terrorism or losing direction? British Journal of Educational Studies, 64, 21-35. doi:10.1080/00071005.2015.1107023

Ecclestone, K. (2012). From emotional and psychological well-being to character education: Challenging policy discourses of behavioural science and 'vulnerability'. Research Papers in Education, 7, 463-480.

Ecclestone, K., \& Hayes, D. (2009). The dangerous rise in therapeutic education. London: Routledge.

Esposito, R. (2013). Terms of the political: Community, immunity, biopolitics. New York, NY: Fordham.

Forth, C. (2001). Moral contagion and the will. In E. Bashford \& C. Hooker (Eds.), Contagion (pp. 61-75). London: Routledge. Foucault, M. (2003). Abnormal. London: Picador.

Foucault, M. (2005). The hermeneutics of the subject. London: Picador.

Foucault, M. (2006). Psychiatric power. New York, NY: Palgrave Macmillan.

Foucault, M. (2007). Security, territory, population. London: Palgrave MacMillan.

Fricker, M. (2007). Epistemic injustice: Power and the ethics of knowing. Oxford: Oxford University Press.

Gatens, M., \& Lloyd, G. (1999). Collective imaginings: Spinoza past and present. London: Routledge.

Gilroy, P. (2004). Postcolonial melancholia. New York, NY: Columbia University Press.

Giroux, H. (2003). Public spaces, private lives: Democracy beyond 9/11. New York, NY: Rowman and Littlefield.

Githens-Mazer, J. (2010). Rethinking the causal concept of Islamic radicalisation. Political Concepts: Committee on Concepts and Methods Working Paper Series, Mexico City, C\&M.

Githens-Mazer, J. (2012). The rhetoric and reality: Radicalization and political discourse. International Political Science Review, 33, 556-567. doi:10.1177/0192512112454416

Goffman, E. (1987). Asylums, essays on the social situation of mental patients and other inmates. Arizona: Peregrine Books. 
Hadjimatheou, K. (2011). Moral risks of profiling in counter-terrorism. Seventh Framework Programme. Retrieved from http:// www.detecter.bham.ac.uk/pdfs/D5_4_Moral_Risks_of_Profiling_in_Counter-Terrorism.doc $\square$

Heath-Kelly, C. (2012). Re-inventing prevention or exposing the gap? False positives in UK terrorism governance and the quest for pre-emption Critical Studies on Terrorism, 5, 69-97.

Heath-Kelly, C. (2013). Counter-terrorism and the counter-factual: Producing the'radicalisation' discourse and the UK PREVENT strategy. The British Journal of Politics and International Relations, 15, 394-415. doi:10.1111/j.1467-856X.2011.00489.x

Hickman, M., Thomas, L., Nickels, H., \& Silvestri, S. (2012). Social cohesion and the notion of 'suspect communities': A study of the experiences and impacts of being 'suspect' for Irish communities and Muslim communities in Britain. Critical Studies on Terrorism, 5, 89-106.

Hillyard, P. (1993). Suspect community: People's experiences of the Prevention of Terrorism Acts in Britain. London: Pluto Press. HM Government. (2011). Prevent strategy review. Crown Copyright.

HM Government. (2012). Channel: Vulnerability assessment framework. Crown Copyright.

HM Government. (2013). Tacking extremism in the UK. Crown Copyright.

HM Government. (2015). Channel duty guidance. Crown Copyright.

Home Office. (2011). Understanding vulnerability and resilience in individuals to the influence of Al Qa'ida extremism. Occasional Paper 98, Home Office, London.

Hook, D. (2010). Foucault, psychology and the analytics of power. London: Palgrave.

Horgan, J. (2008a). From profiles to pathways and roots to routes: Perspectives from psychology on radicalization into terrorism. The ANNALS of the American Academy of Political and Social Science, 618, 80-94.

Horgan, J. (2008b). Deradicalization or disengagement? A process in need of clarity and a counterterrorism initiative in need of evaluation. Perspectives on Terrorism, 22. Retrieved July 1, 2015, from http://www.terrorismanalysts.com/pt/ index.php/pot/article/view/32/html

Horgan, J. (2014). The psychology of terrorism. London: Routledge.

House of Commons. (2010). Preventing violent extremism. Retrieved March 20, 2015, from http://www.publications. parliament.uk/pa/cm200910/cmselect/cmcomloc/65/65.pdf

Jackson, R. (2008). Counter-terrorism and communities: An interview with Robert Lambert. Critical Studies on Terrorism, 1 , 293-308. doi:10.1080/17539150802184678

Kundnani, A. (2006, May). Criminalising dissent in the 'War on Terror'. Institute of Race Relations. Retrieved December 11, 2014, from http://www.irr.org.uk/2006/may/ak000006.html

Kundnani, A. (2009). Spooked: How not to prevent violent extremism. Institute of Race Relations. Retrieved December 11, 2014, from http://www.irr.org.uk/pdf2/spooked.pdf

Kundnani, A. (2012). Radicalisation: The journey of a concept. Race and Class, 54, 3-25. doi:10.1177/0306396812454984

Kundnani, A. (2014). The Muslims are coming: Islamophobia, extremism, and the domestic war on terror. New York, NY: Verso.

Kundnani, A. (2015, January). A decade lost: Rethinking radicalisation and extremism. Retrieved from http://mabonline.net/ wp-content/uploads/2015/01/Claystone-rethinking-radicalisation.pdf

Le Bon, G. (2001). The crowd: A study of the popular mind. Kitchener: Batoche Books.

Le Doeuff, M. (1989). The philosophical imaginary. Stanford: Stanford University Press.

Macdonald, M., \& Hunter, D. (2013). Security, population and governmentality: UK Counter-terrorism discourse (2007-2011). Critical Approaches to Discourse Analysis across Disciplines, 7, 123-140.

Martin, T. (2014). Governing an unknowable future: The politics of Britain's prevent policy. Critical Studies on Terrorism, 7 , 62-78.

McCulloch, J., \& Pickering, S. (2009). Pre-crime and counter-terrorism: Imagining future crime in the 'war on terror'. British Journal of Criminology, 49, 628-645.

Mythen, G. (2012). "No one speaks for us": Security policy, suspected communities and the problem of voice. Critical Studies on Terrorism, 5, 409-424. doi:10.1080/17539153.2012.723519

Mythen, G., Walklate, S., \& Khan, F. (2009). "I'm a Muslim but I'm not a Terrorist": Victimisation, risky identities and the performance of safety. British Journal of Criminology, 49, 736-754. doi:10.1177/0038038512444811

O'Donnell, A. (2016). Securitisation, counterterrorism and the silencing of dissent: The educational implications of prevent. British Journal of Educational Studies, 64, 53-76. doi:10.1080/00071005.2015.1121201

Orwell, G. (1961). 1984. New York, NY: Penguin.

Pantazis, C., \& Pemberton, S. (2009). From the "old" to the "new" suspect community: Examining the impacts of the recent UK counter-terrorist legislation. British Journal of Criminology, 49, 646-666.

Pantazis, C., \& Pemberton, S. (2011). Restating the case for the "suspect community". British Journal of Criminology, 51 , 1054-1062.

Richards, A. (2011). The problem with 'radicalization': The remit of 'Prevent' and the need to refocus on terrorism in the UK. International Affairs, 87, 143-152.

Rogers, P. (2008). Contesting and preventing terrorism: On the development of UK strategic policy on radicalisation and community resilience. Journal of Policing, Intelligence and Counter Terrorism, 3, 38-61. doi:10.1080/18335300.2008.96 86913 
Russell Group. (2015). Russell Group response to the consultation on the Counter- Terrorism Bill draft statutory guidance. Retrieved September 4, 2015, from http://www.russellgroup.ac.uk/uploads/57-Russell-Group-response-to-consultationon-the-Prevent-duty-guidance-as-described-by-the-Counter-Terrorism-and-Secrurity-Bill-2015.pdf

Sageman, M. (2014). The stagnation in terrorism research. Terrorism and Political Violence, 26, 565-580. doi:10.1080/0954 6553.2014.895649

Schmid, A. (2013). Radicalisation, de-radicalisation, counter-radicalisation: A conceptual discussion and literature review. The Hague: ICCT Research Paper.

Sedgwick, M. (2010). The concept of radicalization as a source of confusion. Terrorism and Political Violence, 22, 480-501.

Spalek, B. (2011). 'New' terrorism and crime prevention initiatives involving young people in the UK: Research and policy contexts. Religion, State and Society, 39, 191-207.

Stares, P., \& Yaboubian, M. (2007). Terrorism as a disease: An epidemiological model for countering Islamic extremism. Pittsburgh, PA: Ridgeway Center.

Stares, P., \& Yacoubian, M. (2012). Rethinking the 'War on Terror': New approaches to conflict prevention and management in the post-9/11 world. In C. Crocker, F. Hampson, \& P. Aall (Eds.), Leashing the dogs of war: Conflict management in a divided world (pp. 425-436). Washington, DC: United States Institute of Peace Press.

Tully, J. (1995). Strange multiplicity. Cambridge: Cambridge University Press. 